\title{
Comparative Analysis on Use of Polymer Fibres from Recycled Polyethylene Terephthalate into Reinforced Concrete Solutions
}

\author{
IMRE KISS ${ }^{1 *}$, ILARE BORDEASU ${ }^{2 *}$, ANDREI MIHAI BACIU ${ }^{1}$, VASILE ALEXA ${ }^{1}$, \\ VASILE GEORGE CIOATA ${ }^{1}$, GABRIEL URSU-NEAMT ${ }^{2}$ \\ ${ }^{1}$ University Politehnica Timisoara, Faculty of Engineering Hunedoara, Department of Engineering \& Management, \\ 5 Revolutiei, 331128, Hunedoara, Romania \\ ${ }^{2}$ University Politehnica Timisoara, Faculty of Mechanical Engineering, 1 Mihai Viteazu Blvd., 300222, Timisoara, Romania
}

\begin{abstract}
Fibre-reinforced concrete cannot replace the ordinary reinforced concrete. However, there are areas of use in which fibre-reinforced concrete can be used alternatively or in addition to the ordinary reinforced concrete, offering several advantages, some of that being presented in this study. The basic idea is that reinforcements create a multi-directional "mesh" within the cementitious matrix that will make concrete stronger. In fact, adding the fibrous material to concrete will increase the strength. In this sense, the micro-fibres primarily work to prevent micro-or shrinkage cracking, which mostly occurs during the initial curing process of the concrete, or those critical first 28 days. By contrast, the macro-fibres provide load-bearing strength after the concrete cracks. But, in fact, the subject is more complex. The types and size of fibres, their distribution and orientation are a hugely complex topic. Fibres, of whatever nature, have been found to improve the properties of concrete. Fibre-reinforced concrete provides an alternative to conventional reinforcement, with the advantage of time and reduced costs of performing maintenance work. The complexity of various fibre use presents challenges for the construction sectors that may be beyond current levels of expertise. In this study, particularities of concrete reinforced with polymer fibres are presented. Also, a comparative study is presented, based on our previous works in area of the concrete reinforcing with recycled polyethylene terephthalate (PET).
\end{abstract}

Keywords: fibre-reinforced concrete, polymer fibres, recycled PET, comparative study

\section{Introduction}

Many constructions require precise techniques and technologies that can use a number of new building materials [1-8]. In this context, the use of concrete is somewhat restricted by specific phenomena such as cracking, shrinkage or durability. The concrete has numerous and significant technical and economic advantages, which have attracted the attention of specialists [1-4,7-25]. For this reason, various studies and research have been made, which have led to improvements in its performance. One of the ways of improvement can be achieved by adding in their mass of dispersed reinforcements, in the form of different type of fibers [1-4,7-25]. The dispersed reinforced concrete results in the inclusion of a variable amount of discontinuous fibres in the concrete mass [1-4,7-25]. These fibres can be of different types and sizes and have different properties.

A properly proportioned concrete mixture will possess the desired workability for the fresh concrete and the required strength for the hardened concrete [1-4]. A typically concrete mixture by volume is about 60 to $75 \%$ fines sand and coarse aggregates, 10 to $15 \%$ cement, and 15 to $20 \%$ water (Figure 1). Entrained air bubbles in many concrete mixtures may also take up another 5 to $8 \%$ by volume (Figure 2) [1-4,19-21]. Concrete can be moulded or formed into any shape when newly mixed, strong and durable when hardened [1-4]. The key to achieving a strong, durable concrete rests on the careful proportioning and mixing of the ingredients (Figure 3) [1-4, 12-16].

\footnotetext{
*email: imre.kiss@upt.ro,ilarica59@gmail.com
} 


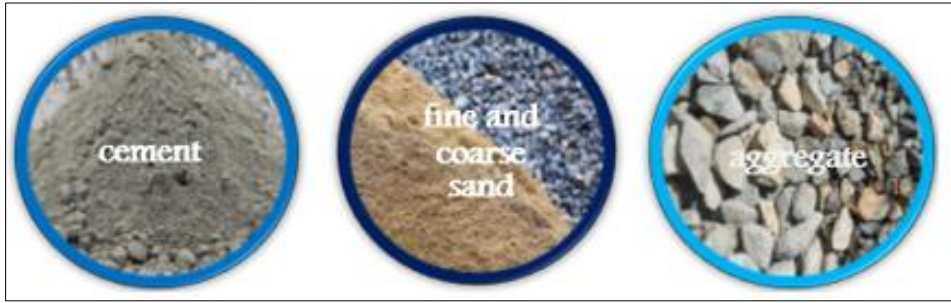

Figure 1. Solid factions of the concrete recipe

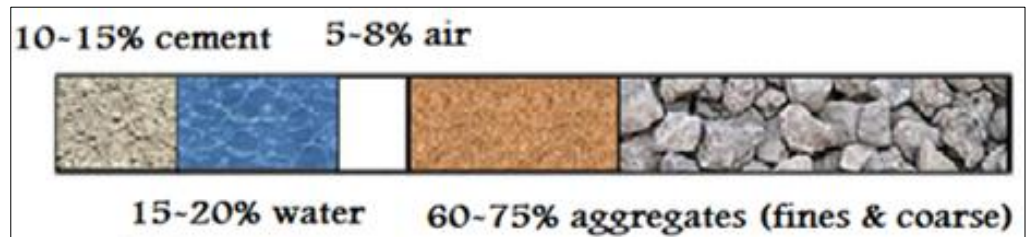

Figure 2. Typically concrete mixture

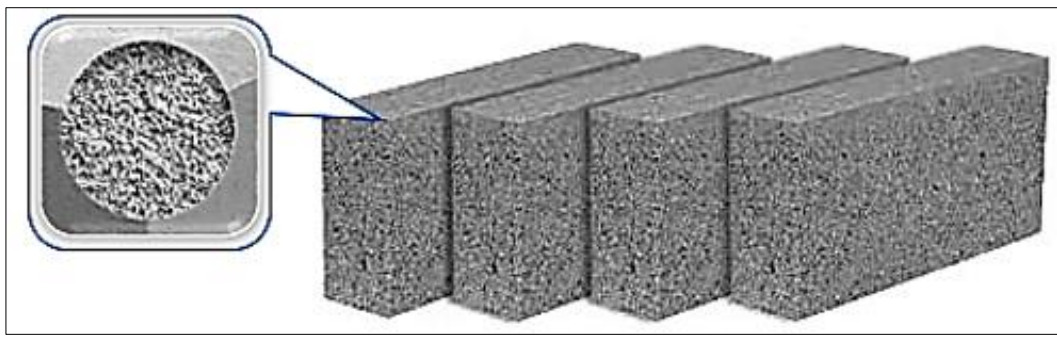

Figure 3. The concrete structure



Figure 4. Fibres for reinforcing concretes

Generally, most fibres are either steel (straight, waved, fattened, crescent or hooked) or polymeric, which defines their composition as polypropylene (monofilament and/or fibrillated), polyethylene or polyester. Other types of fibres include, but are not limited to, natural (wood or plant), mineral (basalt), glass and carbon (Figure 4). Research into new fibre-reinforced concretes continues today [1-4,7-25]. Also, several studies concludes that hybrid reinforcements (steel and polypropylene fibres) showed improved characteristics and mechanical properties of concretes $[12,17,18]$.

A range of fibre reinforced concrete mixes are produced, which include steel fibres, various polymer fibres (polypropylene or polypropylene fibres), or another synthetic fibres [1-4,7-20]. Fibre-reinforced concrete contain fibrous materials which increases its structural integrity, containing uniformly distributed or randomly oriented short fibres (steel, glass, synthetic and natural fibres), each of that lend 
varying properties to the concrete [1-4, 7-20]. In addition, the character of fibre-reinforced concrete changes with varying reinforced materials, with various geometries, orientation, distribution, densities and proportion in the concrete mix [1-4, 7-20]. Adding the various reinforcements to concrete will increase the strength $[1-4,7-25]$. The basic idea is that reinforcements in the mix will create a multidirectional "mesh" within the cementitious matrix that, when are used correctly and in proper proportions, will make the concrete stronger. But, in fact, the subject is more complex. The types and size of fibres, and their distribution and orientation in the cementitious matrix, constitutes a hugely complex topic.

Polymer fibres are utilized in diverse applications, such as industrial floors, wind turbine blades, bridges or prefabricated products [9-25]. The amount of polymer fibres added to concrete is expressed as a percentage of the total volume of the cement-based composite, typically ranges up to 3\% (Figure 5) $[7,8]$.

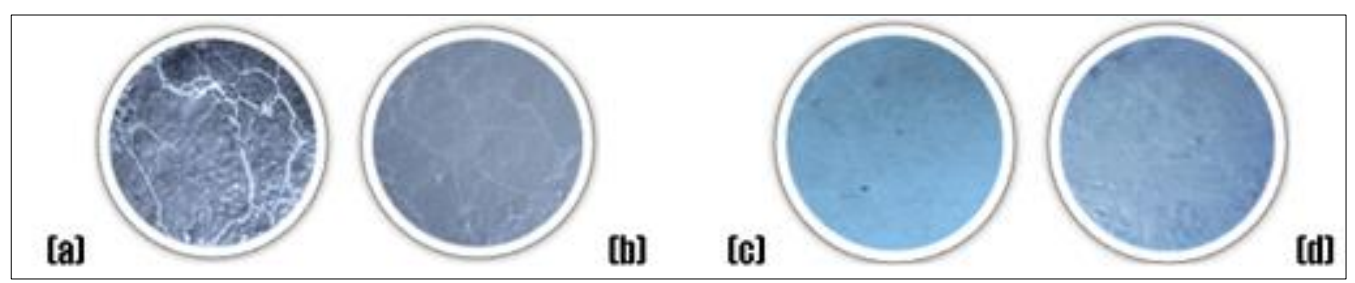

Figure 5. Shrinkage of concrete [7, 8]

(a) without fibre; (b) with $0.1 \%$ fibre; (c) with $0.2 \%$ fibre; (d) with $0.3 \%$ fibre

Polymer fibres, such as polyethylene or polypropylene fibres, are mainly used to reduce concrete contraction and increase the fire resistance [20-24]. They are not designed to replace structural reinforcement, the use of polymer fibres being prevalent when providing the following solutions:

- strengthening the concrete and the abrasion resistant layer;

- protection against the formation of minuscule cracks due to the concrete's shrinkage; and

- excellent resistance against chemical and aggressive materials attacks.

For the dispersed reinforcement of concrete, polymer fibres, alone or in combination with steel fibres, were investigated in several works [7-25]. Of these, the most indicated are polypropylene or polyethylene fibres. Several research has shown that reinforcing with $0.1 \%$ polyethylene fibres is sufficient to absorb the internal stresses resulting from the contractions of concrete [14-18,24]. Regarding the systematic researches in the field of reinforced concrete dispersed with polyethylene fibres, it can be said that they are still at a less developed stage $[7,8]$.

\section{Materials and methods}

In view of the above, solutions are being sought for the creation of new types of concrete, including the dispersed ones. Therefore, different types of synthetic fibres are often used in concrete. At present, the objective is to identify and use alternative raw materials. Thus, fibres, of whatever nature, improve the properties of concrete (Figure 6) [7-25]. Our previous results presented in [7,8] indicate promising possibilities of using recycled polyethylene terephthalate (PET) in concrete products. At the same time, such applications would contribute to solving the problem of waste polyethylene terephthalate (PET) disposal.

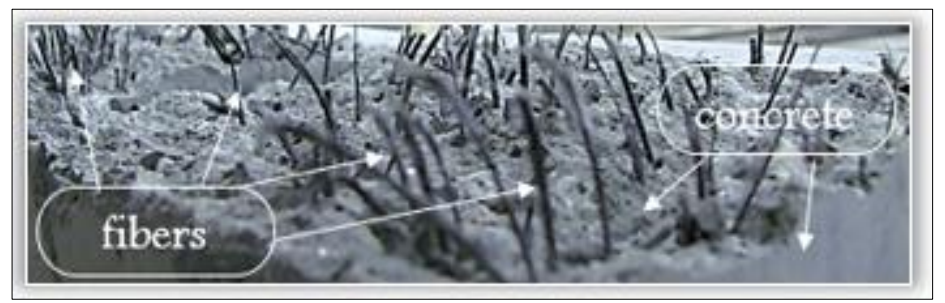

Figure 6. Fibre-reinforced concrete 
The present work refers to the concrete in which the dispersed reinforcement is made of polymeric materials. All the reinforcements used in this work to consolidate the ceramic composite materials dispersed reinforced concrete type - were made from material from a mix of polyethylene terephthalate (PET) packages, of different types and characteristics, which are found daily in supermarkets and which then reach waste (Figure 7).

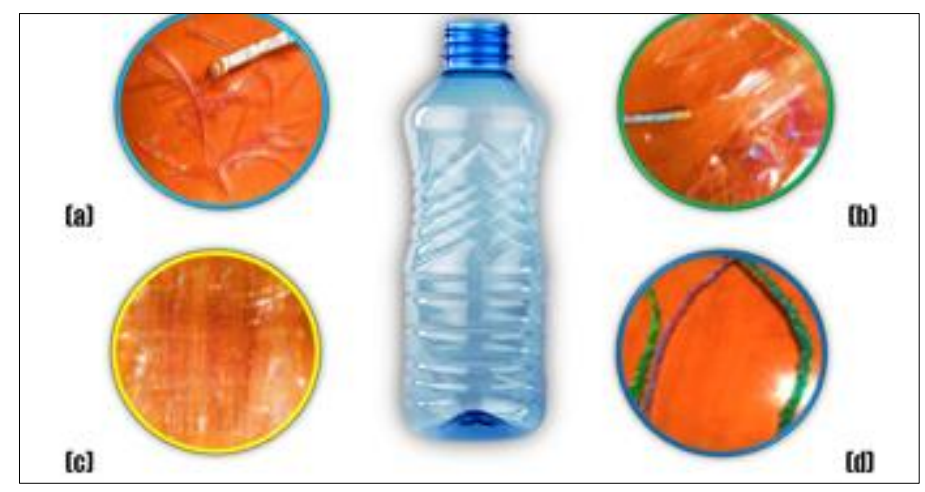

Figure 7. Preparing the PET reinforcements [7,8]: a) PET flat strips;

b) PET chips c) PET mesh-shaped braids; d) PET rope strand

Non-reinforced concrete (class C30/37) and reinforced concrete dispersed with reinforcements from polyethylene terephthalate (PET) waste were made in laboratory conditions. Non-reinforced concrete (class C30/37) is based on the following materials: water, Portland cement, sand (sort 0-4 mm) and gravel (sorts $4-8 \mathrm{~mm}$ and $8-16 \mathrm{~mm}$ ) and additives, in proportion of about $77 \%$ aggregate, $15 \%$ cement and $8 \%$ water $[7,8]$. The concrete used in all the 5 samples (1 non-reinforced and 4 reinforced with recycled polyethylene terephthalate), was one and the same, with the same characteristics (class C30/37). In this way, the influence of the reinforcements on the compression characteristics was followed $[7,8]$.

In the first of the reinforcement methods, the extraction of flat strips from polyethylene terephthalate (PET) packaging was chosen. (Figure 7a) The second reinforcement method uses reinforcements in the form of chips from polyethylene terephthalate (PET) packaging (Figure 7b). In the third of the concrete reinforcement methods, the extraction of yarns from polyethylene terephthalate (PET) packaging was chosen, followed by a mesh-shaped braiding process (Figure 7c). The fourth concrete reinforcement method uses reinforcements in the form of polymer rope, obtained from weaving the polyethylene terephthalate (PET) long yarns (Figure 7d).

The determination of the volumetric mass (density) is made according to [26]. The determination of the compressive strength of the reinforced concrete (at 28 days) is determined according to [27] and [28], based on the cubic strength test carried out on a minimum number of three samples of cubic form (Figure 8). The experimental steps of concrete casting and reinforcing and the test on reinforced concrete samples are presented in Figures 9 and 10 [7,8]. The compressive strength tests on concrete samples $(1$ non-reinforced concrete and 4 reinforced with PET fibres) are presented in Figure 11 [7,8].

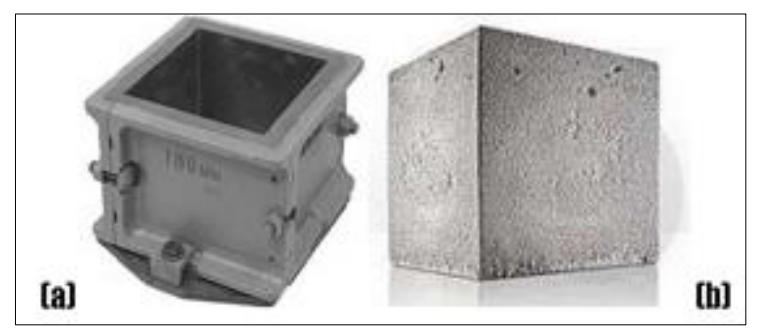

Figure 8. Preparing the samples $[7,8]$

(a) $15 \mathrm{~cm}$ cube mould; (b) concrete cube sample 




[a]

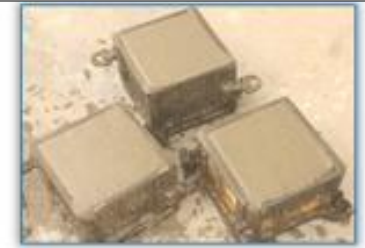

[b]

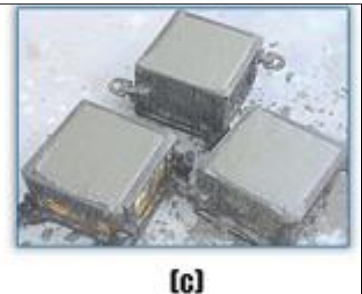

[c]

Figure 9. Casting the concrete samples $[7,8]$

(a) experiments no.1-3; (b) experiment no.4; (c) experiment no.5

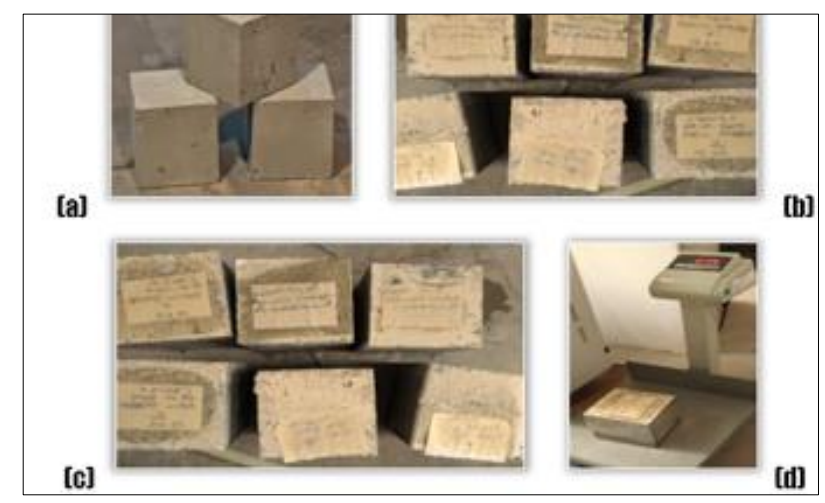

Figure 10. Concrete cube samples, their labelling and weighing [7,8]

(a) non-reinforced concrete; (b) concrete reinforced with recycled polyethylene terephthalate (PET flat strips; PET chips); (c) concrete reinforced with recycled polyethylene terephthalate (PET mesh-shaped braids; PET rope strand); (d) weighing of the concrete samples

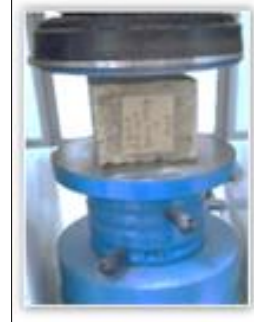

[a]

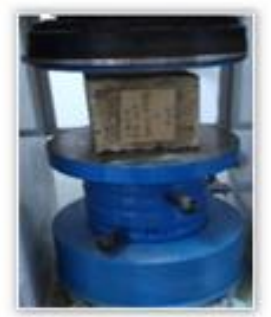

[b]

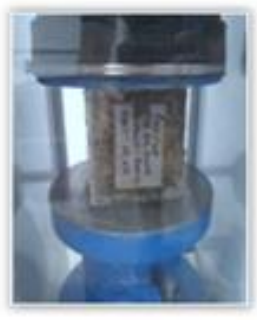

[c]

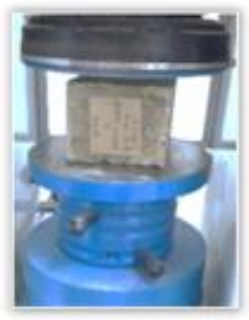

[d]

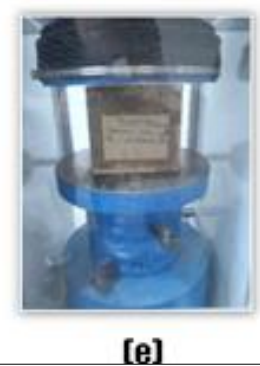

[e]

Figure 11. Tests on compressive strength of the reinforced concrete (at 28 days) $[7,8]$

(a) non-reinforced concrete; (b)-(e) concrete reinforced with recycled polyethylene

(b) terephthalate (PET flat strips; PET chips; PET mesh-shaped braids; PET rope strand)

\section{Results and discussions}

The experimental results presented in $[7,8]$ indicated that the dosage and form of the reinforcements are the two most influential parameters in the concrete reinforcing process. For a given volume fraction of recycled polyethylene terephthalate ( $12 \mathrm{~g})$, changing the fibre form (width, length, thickness) we experimented several reinforcing possibilities, large presented in [7,8]. Also, decreasing the fibre profile or equivalently increasing the number of fibres in the concrete mix significantly improves the compressive strength. At a volume fraction of $0.6 \%$, most tested fine-diameter recycled polyethylene terephthalate (stripes and flakes) provided a reasonable increase of the reinforced concrete compressive strength (Figure 12, Table 1), without unnecessarily adding to the density of concrete reinforced with recycled polyethylene terephthalate (Figure 13, Table 1) [7,8]. 


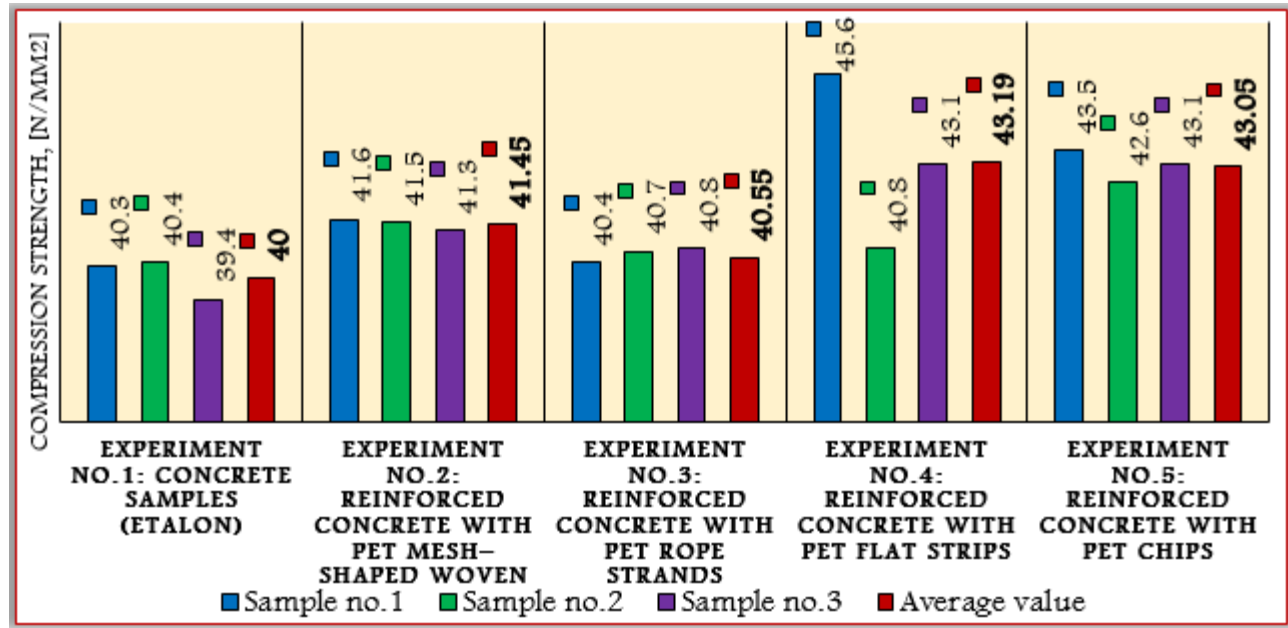

Figure 12. Comparison between the obtained compression strength of concrete reinforced with recycled polyethylene terephthalate (PET) $[7,8]$

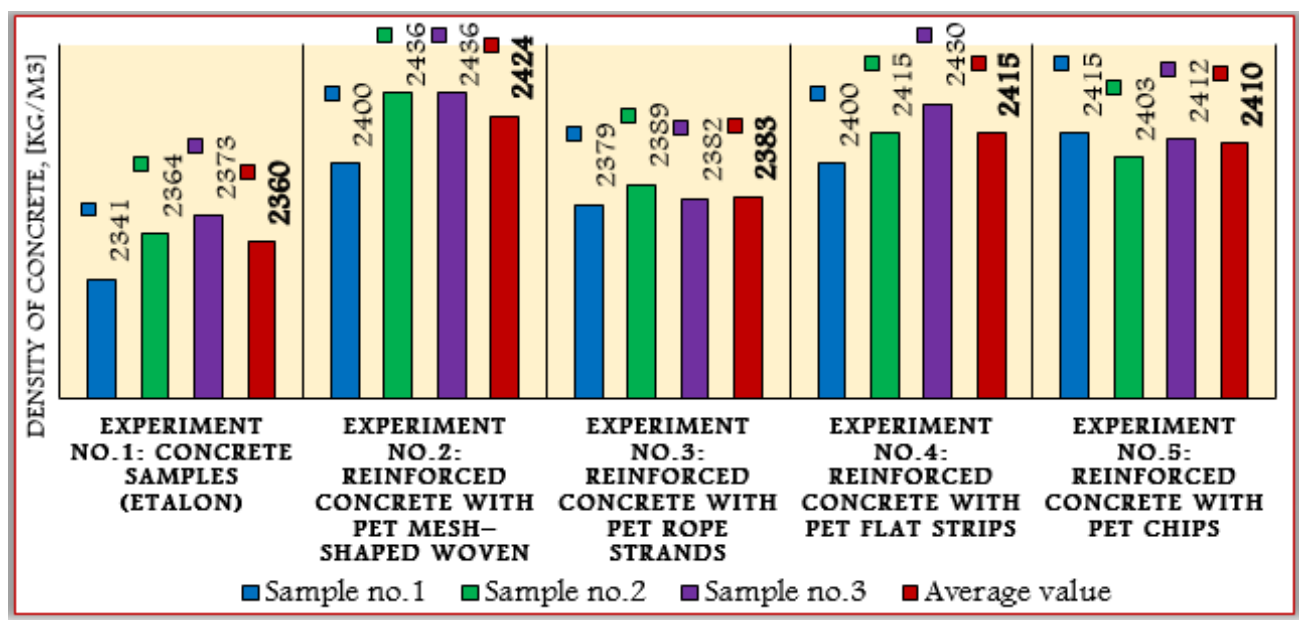

Figure 13. Comparison between the obtained density of concrete reinforced with recycled polyethylene terephthalate (PET) [7,8]

Table 1. Experimental values - synthesis of the experiments

\begin{tabular}{|c|c|c|c|c|c|}
\hline \multirow{2}{*}{ No. experiment } & \multirow{2}{*}{ Characteristics } & \multicolumn{4}{|c|}{ Experimental values } \\
\hline & & 1 & 2 & 3 & Average value \\
\hline \multirow{2}{*}{$\frac{\text { EXPERIMENT \#1: Concrete samples }}{\text { (etalon) }}$} & $\begin{array}{c}\text { Compression strength, } \\
{\left[\mathrm{N} / \mathrm{mm}^{2}\right]}\end{array}$ & 40.3 & 40.4 & 39.4 & 40.0 \\
\hline & Density of concrete, $\left[\mathrm{kg} / \mathrm{m}^{3}\right]$ & 2341 & 2364 & 2373 & 2360 \\
\hline \multirow{2}{*}{$\begin{array}{l}\text { EXPERIMENT } \# 2 \text { : PET mesh-shaped } \\
\text { woven' reinforced concrete samples }\end{array}$} & $\begin{array}{c}\text { Compression strength, } \\
{\left[\mathrm{N} / \mathrm{mm}^{2}\right]}\end{array}$ & $\begin{array}{c}(\mathrm{Ctrl})= \\
+1.0\end{array}$ & 41.5 & 41.3 & 41.45 \\
\hline & Density of concrete, $\left[\mathrm{kg} / \mathrm{m}^{3}\right]$ & 2400 & 2436 & 2436 & 2424 \\
\hline \multirow{2}{*}{$\begin{array}{c}\text { EXPERIMENT \#3: PET rope strands' } \\
\text { reinforced concrete samples }\end{array}$} & $\begin{array}{c}\text { Compression strength, } \\
{\left[\mathrm{N} / \mathrm{mm}^{2}\right]}\end{array}$ & 40.4 & 40.7 & 40.8 & 40.55 \\
\hline & Density of concrete, $\left[\mathrm{kg} / \mathrm{m}^{3}\right]$ & 2379 & 2389 & 2382 & 2383 \\
\hline \multirow{2}{*}{$\begin{array}{c}\text { EXPERIMENT \#4: PET flat strips' } \\
\text { reinforced concrete samples }\end{array}$} & $\begin{array}{c}\text { Compression strength, } \\
{\left[\mathrm{N} / \mathrm{mm}^{2}\right]}\end{array}$ & 45.6 & 40.8 & 43.1 & 43.19 \\
\hline & Density of concrete, $\left[\mathrm{kg} / \mathrm{m}^{3}\right]$ & 2400 & 2415 & 2430 & 2415 \\
\hline \multirow{2}{*}{$\begin{array}{l}\text { EXPERIMENT \#5: PET chips' } \\
\text { reinforced concrete samples }\end{array}$} & $\begin{array}{c}\text { Compression strength, } \\
{\left[\mathrm{N} / \mathrm{mm}^{2}\right]}\end{array}$ & 43.5 & 42.6 & 43.1 & 43.05 \\
\hline & Density of concrete, $\left[\mathrm{kg} / \mathrm{m}^{3}\right]$ & 2415 & 2403 & 2412 & 2410 \\
\hline
\end{tabular}


The results in the 4 concretes reinforced with recycled polyethylene terephthalate in Figure 14 are presented. In interpreting the results, the comparative analysis followed the types of reinforcements used in experiments, the time of production of reinforcements from different polymer (PET) fibers, the increase in resistance obtained by the reinforcement method, and the complete feasibility of each reinforcement method.

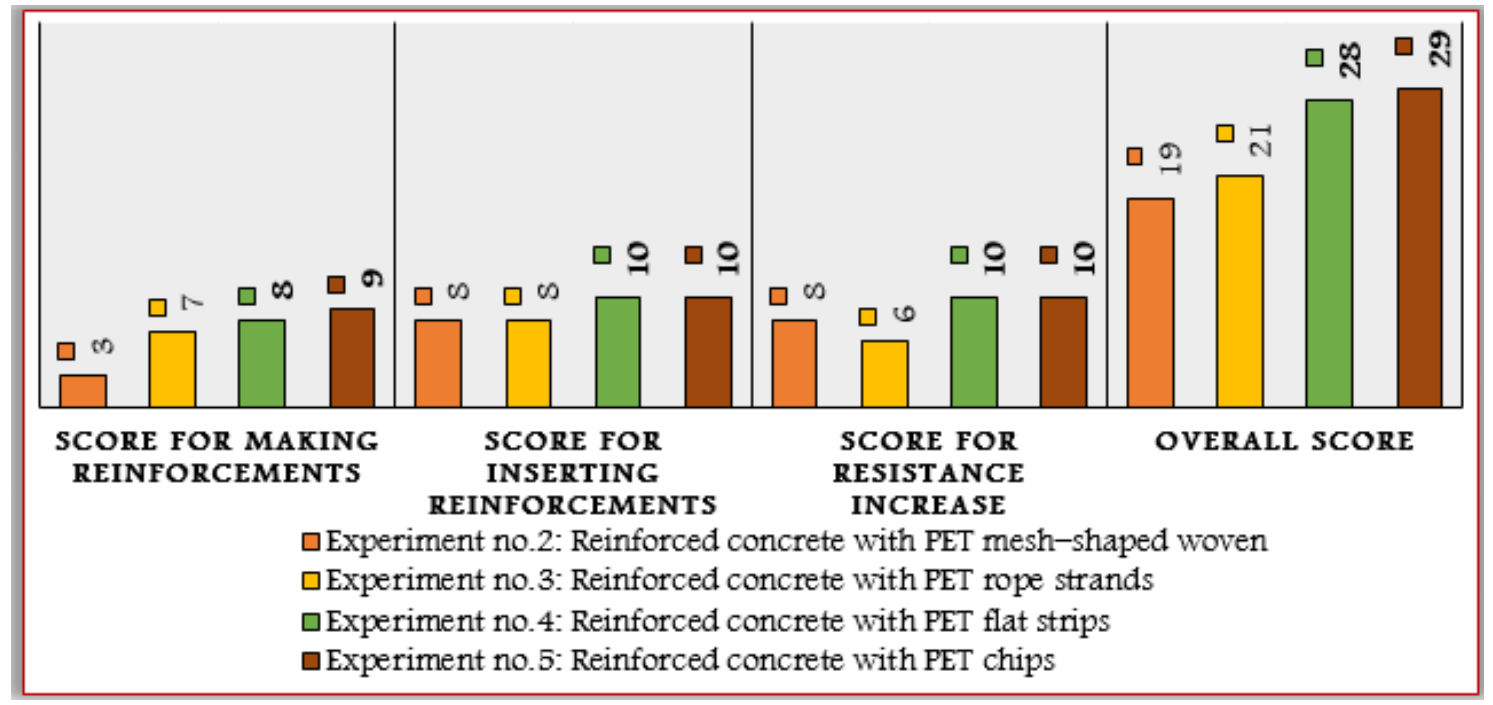

Figure 14. The interpretation of the results in the 4 concretes reinforced with recycled polyethylene terephthalate $[7,8]$

Scores were awarded on a scale of 1 to 10 (1 being minimum and meaning weak and 10 being maximum and meaning very good). Scores for the preparation of recycled polyethylene terephthalate reinforcements represent the difficulties or ease in the making of the reinforcements, taking into account the need to manufacture special tools and working equipments, as well as the actual time to make the reinforcement types. The assembling/inserting score is the degree of difficulty with which the various recycled polyethylene terephthalate reinforcements are mounted and the time required to be made.

As can be seen from the comparative graph obtained on the base of the overall score presented in Figure 14, by far the most feasible and productive methods of reinforcement are those with dispersed reinforcement, namely flat fibre and chip reinforcements. These two reinforcement methods are carried out easily, without too many adjacent machines, in a relatively short time compared to the other two methods (both as the realization of the reinforcements and as their assembling/inserting). Moreover, this also represents the fact that these two reinforcement methods, in addition to being carried out easily and in relatively short time, are also the most productive when it comes to increasing the compressive strength of the cement matrix.

Regarding the relative poor results obtained by the braided mesh and the rope strands from recycled polyethylene terephthalate reinforcements, it should be noted that they lend themselves much better on stretching loads and thus compression loading does not show major improvements. For this reason, we will then analyse these two methods in a study on stretching load.

\section{Conclusions}

There are multiple reasons for adding polymer fibres in concrete, including the recycled polyethylene terephthalate reinforcements. In fact, choosing the right polymer fibre mostly depends on the type of application. Among the advantages of using polymer fibres into the concretes are the following, being perfectly aware that we can even include all:

-one of the main benefits of polymer fibres are the homogenous distribution in the concrete. Other benefits include the better cohesion of the fresh concrete; also, thanks to extreme durability of polymers 
the fibre retain their full characteristics during entire concrete; the use of polymer fibres in the concrete composition increases its compressive strength;

-addition of polymer fibres requires a lower processing costs, compared to steel reinforcements. The advantages of using reinforced concrete with polymer fibres are evident in the small prefabricated building materials, where the costs of reinforcement with bars are high; the addition of polymer fibres save time in the construction process and reduce costs;

-the use of dispersed polymer fibres determine a reduced weight of prefabricated reinforced concrete, and therefore, traditional mesh and steel fibre reinforcement may be avoided. The polymer fibres replace or partially replace traditional reinforcing steel;

The development of the construction sector, in particular the investments in infrastructure, remain the key factors of the economic growth. This implies a strong increase in the consumption of building materials in times of economic boom, and against the background of the significant increase in demand, the needs of raw materials also increase. Concrete is one of the main materials used in construction, therefore, the consumption of concrete is determined by the state of the construction industry. Being easy to use, dosed industrial or into a simply concrete mixer, the polymer fibres save time compared to traditional mesh application.

\section{References}

1.BEAUDOIN, J.J., Handbook of fibre-reinforced concrete. Principles, properties, developments and applications, 1990

2.JOHNSTON, C.D., Fibre-reinforced cements and concretes. CRC Press, 2014

3.UDDIN, N. (ed.), Developments in fibre-reinforced polymer (FRP) composites for civil engineering, Elsevier, 2013

4.BORDEASU, I., MITELEA, I., LAZAR, I., MICU, L. M., KARANCSI, O., Cavitation Erosion Behaviour of Cooper Base Layers Deposited by HVOF Thermal Spraying, Rev. Chim., 68(12), 2017, pp. 2914-2917 https://doi.org/10.1115/1.4032489

5.MITELEA, I., MICU, L. M., BORDEASU, I., CRACIUNESCU, C. M., Cavitation Erosion of Sensitized UNS S31803 Duplex Stainless Steels, Journal of Materials Engineering and Performance, 25(5), 2016, pp.1939-1944 https://doi.org/10.1007/s11665-016-2045-0

6.BEJ, A., BORDEASU, I., MILOS, T., BADARAU, R., Considerations concerning the mechanical strength of wind turbine blades made of fibreglass reinforced polyester, Mater. Plast., 49(3), 2012, 212218

7.KISS, I., BACIU, A.M., BORDEASU, I., MICU, L.M., Compressive strength of stripes and flakes of recycled polyethylene terephthalate (PET) added concrete, Mater. Plast., 57(1), 2020, 244-252

https://doi.org/10.37358/Mat.Plast.1964

8.BACIU, A.M., KISS, I., BORDEASU, I., MICU, L.M., Compressive strength of woven and strand of recycled polyethylene terephthalate (PET) reinforced concrete, Mater. Plast., 57(1), 2020, 263-271 https://doi.org/10.37358/MP.20.1.5333

9.GRACE, N.F., SAYED, G.A., SOLIMAN, A.K., SALEH, K.R., Strengthening reinforced concrete beams using fibre reinforced polymer (FRP) laminates, ACI Structural Journal-American Concrete Institute, 96(5), 1999, pp. 865-874 https://doi.org/10.14359/741

10.MELO, G.S., Strengthening reinforced concrete beams using fibre-reinforced polymer (FRP) laminates. Discussion. ACI Structural Journal, 97(5), 2000

11.CHAALLAL, O., NOLLET, M.-J., PERRATON, D., Strengthening of reinforced concrete beams with externally bonded fibre-reinforced-plastic plates: Design guidelines for shear and flexure, Canadian Journal of Civil Engineering, 25(4), 1998, pp. 692-704

https://doi.org/10.1139/cjce-25-4-692

12.LAWLER, J.S., ZAMPINI, D., SHAH, S.P. Microfibre and macrofibre hybrid fibre-reinforced concrete, Journal of Materials in Civil Engineering, 17(5), 2005, pp. 595-604

https://doi.org/10.1061/(ASCE)0899-1561(2005)17:5(595) 
13.HERMAN, E, Is fibre-reinforced concrete the material of the future? Aqua Magazine, 2016, https://aquamagazine.com/

14.SONG, P.S., HWANG, S., SHEU, B.C., Strength properties of nylon-and polypropylene-fibrereinforced concretes, Cement and Concrete Research, 35(8), 2005, pp. 1546-1550

https://doi.org/10.1016/j.cemconres.2004.06.033

15.SHARMA, R., PAL BANSAL, P., Use of different forms of waste plastic in concrete - A review, Journal of Cleaner Production, 112(1), 2016, pp. 473-482

https://doi.org/10.1016/J.JCLEPRO.2015.08.042

16.ZOLLO, R.F., Fibre-reinforced concrete: An overview after 30 years of development, Cement and Concrete Composites, 19(2), 1997, pp. 107-122 https://doi.org/10.1016/s0958-9465(96)00046-7

17.YAO, W., LI, J., WU, K., Mechanical properties of hybrid fibre-reinforced concrete at low fibre volume fraction, Cement and Concrete Research, 33(1), 2003, pp. 27-30 https://doi.org/10.1016/S00088846(02)00913-4

18.HSIE, M., TU, C., SONG, P.S., Mechanical properties of polypropylene hybrid fibre-reinforced concrete, Materials Science and Engineering: A, 494(1-2), 2008, pp. 153-157

https://doi.org/10.1016/j.msea.2008.05.037

19.THORNYCROFT, J., ORR, J., SAVOIKAR, P., BALL, R.J., Performance of structural concrete with recycled plastic waste as a partial replacement for sand, Construction and Building Materials, 161, 2018, pp. 63-69 https://doi.org/10.1016/j.conbuildmat.2017.11.127

20.OCHI, T., OKUBO, S., FUKUI, K., Development of recycled PET fibre and its application as concrete-reinforcing fibre, Cement and Concrete Composites, 29(6), 2007, pp. 448-455

https://doi.org/10.1016/j.cemconcomp.2007.02.002

21.GRZYBOWSKI, M., SHAH, S.P., Shrinkage cracking of fibre reinforced concrete, Materials Journal, 87(2), 1990, pp. 138-148 https://doi.org/10.12691/ajcea-5-4-3

22.MOBASHER, B., STANG, H., SHAH, S.P., Microcracking in fibre reinforced concrete, Cement and Concrete Research, 20(5), 1990, pp. 665-676 https://doi.org/10.1016/0008-8846(90)90001-E

23.GOANTA, V., HADAR, A., LEITOIU, B., Experimental procedure designed to determine the elastic characteristics of fibre-reinforced polymeric composite materials, Mater. Plast., 47(4), 2010, 450-456 https://doi.org/10.4028/www.scientific.net/AMM.658.195.0

24.BAYASI, Z., ZENG, J., Properties of polypropylene fibre reinforced concrete, Materials Journal, 90(6), 1993, pp. 605-610 https://doi.org/10.14359/4439

25.SOROUSHIAN, P., LEE, C.-D., Distribution and orientation of fibres in steel fibre-reinforced concrete, Materials Journal, 87(5), 1990, pp. 433-439

26.*** EN 12390-7:2009, Test on reinforced concrete. Part 7: Reinforced concrete density (Încercare pe beton întărit. Partea 7: Densitatea betonului întărit)

27.***SR EN 12390-1:2013, Test on reinforced concrete. Part 1: Shape, dimensions and other conditions for specimens and patterns (Incercare pe beton întărit. Partea 1: Formă, dimensiuni şi alte condiţii pentru epruvete şi tipare)

28.***SR EN 12390-3:2009, Test on reinforced concrete. Part 3: The compressive strength of the specimens (Încercare pe beton întărit. Partea 3: Rezistenta la compresiune a epruvetelor)

Manuscript received: 24.06 .2020 